\title{
Growth response of giant scallops to periodicity of flow
}

\author{
D. J. Wildish ${ }^{1}$, D. D. Kristmanson ${ }^{2}$ \\ ${ }^{1}$ Department of Fisheries and Oceans, Biological Station, St. Andrews, New Brunswick, Canada E0G 2X0 \\ ${ }^{2}$ Chemical Engineering Department, University of New Brunswick, Fredericton, New Brunswick, Canada E3B 5A3
}

\begin{abstract}
Growth experiments with adult giant scallops Placopecten magellanicus (Gmelin) and unfiltered, Bay of Fundy seawater show that optimum flows for filtering/feeding are required for between $>1 / 3$ and $<2 / 3$ of the time so that the scallop can compensate for periods spent at high flows when feeding is restricted or absent. This is consistent with data obtained by others suggesting that bivalves undergo tidal periodicity of feeding and digestion. Seawater with the same seston concentration and of the same nominal flow yields less scallop growth in a tube than in a flume. This is due to limitations of flow mixing in tubes which result in a proportion of the seston being unavailable as food.
\end{abstract}

\section{INTRODUCTION}

The giant scallop Placopecten magellanicus (Gmelin) is a suspension-feeding bivalve mollusc shown to be growth-limited by seawater flow velocities exceeding 10 to $20 \mathrm{~cm} \mathrm{~s}^{-1}$ in the Bay of Fundy (Wildish et al. 1987). Growth in controlled seawater flow experiments of this kind thus appears to yield results at odds with field observations which show that giant scallops are present where tidal current velocities commonly exceed the upper limiting growth velocity for much of the tidal period. For example, giant scallops are present on the Digby beds in the Bay of Fundy where depth-integrated maximum tidal velocities exceed $100 \mathrm{~cm} \mathrm{~s}^{-1}$ (Wildish \& Peer 1983).

Know giant scallop behavioral responses to changing seawater flow velocity include: (1) recessing into the sediment in a characteristic way (Caddy 1968) so that the valves just protrude into the benthic boundary layer where velocities are reduced due to frictional drag on sediments; (2) rotational movements (Bourne 1964) so that the exhalant opening faces away from the direction of the major seawater flow and thus avoids flowinduced feeding inhibition at relatively low flows (Wildish et al. 1987). Experiments have suggested that the mechanism of growth inhibition involves build-up of a pressure differential between inhalant and exhalant openings with increasing flow which interferes with filtration and hence feeding by the scallop (Wild- ish et al. 1988). The inhibitory effect was shown to occur at a lower flow threshold when the scallops were forced to face the current with their exhalant opening and to interact with the quality and quantity of the seston offered as food (Wildish et al. 1987).

The purpose here is to experimentally examine growth responses of giant scallops to different flow regimes which may allow them to persist where tidal velocities commonly exceed their upper limiting growth velocity. The effect of changing current velocity, as occurs during the tidal cycle, was examined at 2 flows: one recognized to be optimal and the other limiting for the giant scallop in the Bay of Fundy (Wildish et al. 1987). In addition, we provide a direct comparison of flume and Kirby-Smith (1972) tube growth because the earlier experiments on scallop growth and flow velocity were conducted in the latter type of apparatus.

Our experiments required the design of a new apparatus to better simulate the hydrodynamic conditions experienced by suspension feeders in natural conditions. The conditions provided in Kirby-Smith growth tubes (Kirby-Smith 1972, Wildish \& Kristmanson 1985) are quite unlike those occurring in the natural benthic boundary layer in the sea. The apparatus constructed is a multiple channel flume which applies the multiple tube idea of Kirby-Smith (1972) to an open-channel flume, thus largely overcoming the simulation difficulties inherent in Kirby-Smith 
growth tubes. With the multiple-channel flume, it is possible to use local seawater and compare growth responses with identical natural seston quality and concentration but with 4 different flow velocities.

\section{MATERIALS AND METHODS}

Adult scallops Placopecten magellanicus of $7.50 \mathrm{~cm}$ average shell length and $60.22 \mathrm{~g}$ average wet weight were used. Scallops were obtained by SCUBA diving in Passamaquoddy Bay, New Brunswick, Canada. They were individually tagged with round, $1 \mathrm{~cm}$ diameter, numbered, plastic discs which were glued to the left valve. They were held in shallow fiberglass tanks supplied with running seawater, which was 1 to $2{ }^{\circ} \mathrm{C}$ higher than the locally available supply, until used in the experiments. Scallops were weighed at the beginning $\left(W_{0}\right)$ and end $\left(W_{1}\right)$ of each experiment after being drained of pallial fluid and gently blotted with tissue paper. Specific daily growth rate was calculated from the experimental duration, $\mathrm{N}$ in days, as:

$$
\frac{W_{1}-W_{0}}{W_{0} \times N} \times 100
$$

They were measured at the longest part of the shell using callipers accurate to $0.1 \mathrm{~mm}$ in the anterior to posterior direction at the beginning $\left(\mathrm{L}_{0}\right)$ and end $\left(\mathrm{L}_{1}\right)$ of the experiment. Specific daily length growth was calculated as:

$$
\frac{\mathrm{L}_{1}-\mathrm{L}_{0}}{\mathrm{~L}_{0} \times \mathrm{N}} \times 100
$$

The flume consisted of a $5 \mathrm{~m}$ long working section, an outlet box leading to a drain and a $7.5 \mathrm{~cm}$ inlet pipe entering on each side of a calming section. The flume was positioned just above the EHWS tide level at the Biological Station and was protected from wind and rain by a small shed built over it. Seawater was pumped to the flume by an $8 \mathrm{hp}$ submerged pump located in the Biological Station tidepool and contained seston of natural quality and concentration for the local area.

Construction throughout was of 13 or $19 \mathrm{~mm}$ marine plywood strengthened by $5 \times 10 \mathrm{~cm}$ braces held in place by bolts. The plywood surfaces were treated with 3 coats of marine resin. Seawater entered the calming section in inlet pipes which were fitted with control valves to regulate water flow. An adjustable weir was used to maintain a constant head pressure in the flume with water passing over the weir going to waste through a $7.5 \mathrm{~cm}$ hole on the calming section bottom. Four screens, two of plywood drilled with 3.8 or $2.5 \mathrm{~cm}$ holes and two of brass or bronze mesh (mesh size: 1.5 to 4 wires per $\mathrm{cm}$ ), were used to calm the turbulent flow produced by pumping seawater into the flume. Before leaving the calming section and entering the 4 flume channels (Fig. 1), the flow of seawater was slightly constricted by narrowing walls and an upward sloping floor to provide a uniform flow at the inlet entrance.
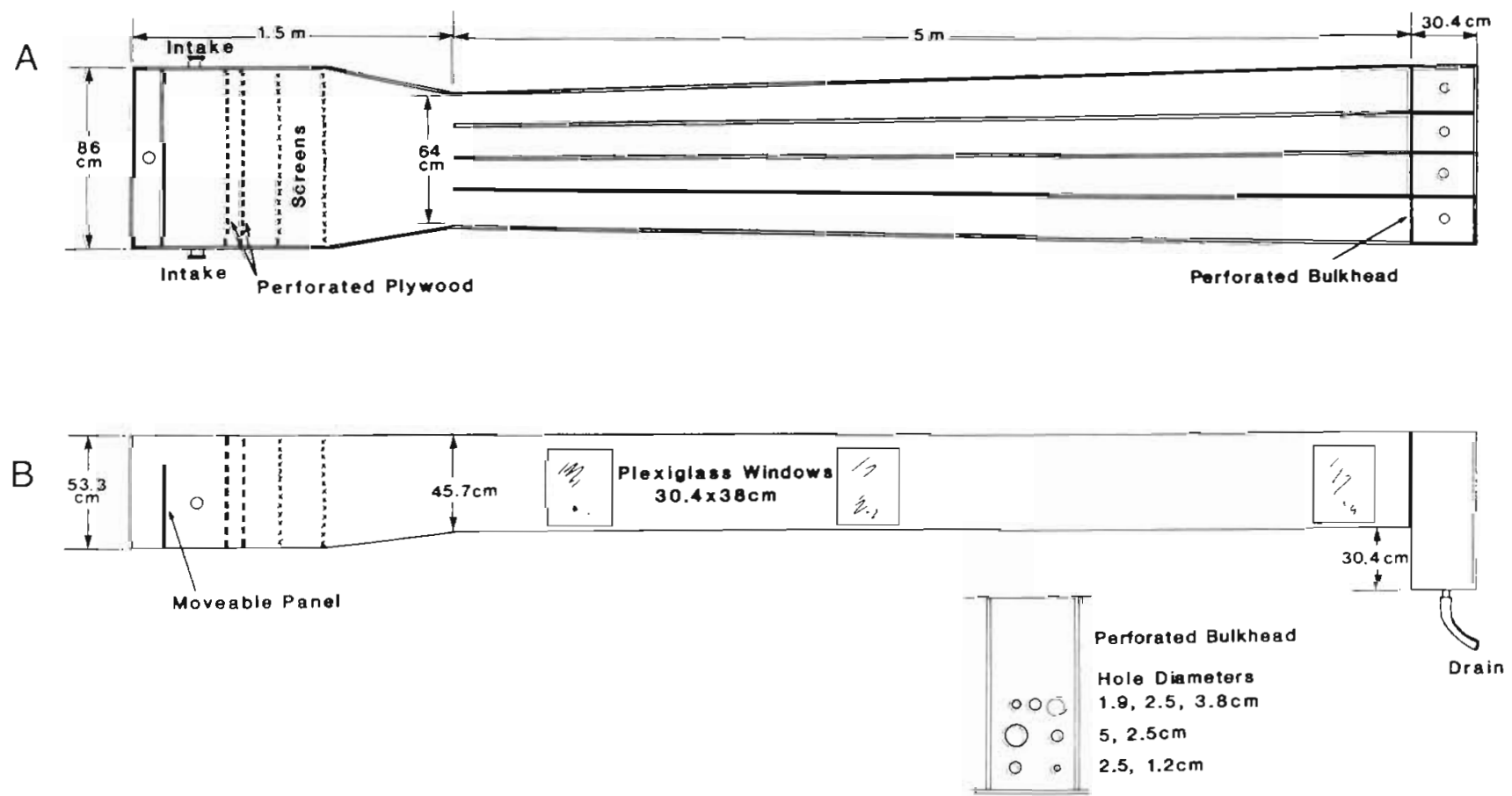

Fig. 1. Multiple channel flume. (A) Plan view: (B) elevation view 
The $5 \mathrm{~m}$ long working section of the flume was divided by plywood walls into 4 equal channels with initial widths in each channel of $15 \mathrm{~cm}$ flaring to $20 \mathrm{~cm}$ at the downstream end. Flaring helps overcome an acceleration in the center of each channel caused by a build-up of wall boundary layers with increasing downstream distance. The flume floor was adjusted so that it was level throughout its $5 \mathrm{~m}$ length.

Each of the channels was fitted with floor molding in the corners and sealed with a non-toxic caulking agent so that there was no water exchange between channels. Three $2 \mathrm{~mm}$ thick Plexiglas windows of $30 \mathrm{~cm}$ width by $38 \mathrm{~cm}$ high were centered at $0.5,1.8$ and $4.31 \mathrm{~m}$ along the channels in both outer working section walls as well as each channel partition wall at this point to facilitate visual and photographic observations. The windows were fitted so that they were flush with the inside walls and were sealed with a caulking agent. Seawater left the working section through a marine plywood bulkhead perforated with round holes of various sizes ( 2 to $5 \mathrm{~cm}$ diameter). The holes could be closed with rubber bungs of appropriate size and thus were used to control the velocity and depth of seawater in the flume.

Seawater was collected in an outlet box from where it went to waste (Fig. 1) or could be shunted to a large tank for recycling with a suitable pump and delivery pipe to the inlet end of the calming section.

Flow measurements. We wished to measure the average free-stream velocity at the midline above the flume boundary layer in each channel. Consequently, we observed the passage time of a nearly neutrally buoyant plastic cylinder, weighted to float just beneath the surface, for a known distance. This flow measure is free of the drag effects seawater undergoes due to its contact with the bottom and with the scallops themselves. The mean speed was calculated based on a minimum of 5 observations (Method 1) for each channel and represented the free-stream velocity integrated over the top $7 \mathrm{~cm}$ of the water column.

This less accurate method was frequently checked against profiling measurements (Method 2) made with a Nixon stream flow probe (Nixon Instrumentation Ltd., 19 Malmesbury Road, Cheltenham, Gloucestershire, GL51 9PL, UK). The Model 403 probe was approximately $40 \mathrm{~cm}$ long, with a $11.6 \mathrm{~mm}$ rotor made of PVC, mounted on a stainless steel spindle and with synthetic jewel bearings. The passage of the rotor blade past a gold wire tip within the long steel tube varies the impedance between the two, thus modulating a $15 \mathrm{KHz}$ carrier signal which is proportional to the flow and is applied to the electronic circuits of a digital indicator (Model 412). The probe was mounted on a frame supporting it over the flume channel which could be worked up or down in steps of $1 \mathrm{~cm}$. Because of a protective cage surrounding the rotor, the rotor blade tip could only be lowered to within $2.5 \mathrm{~mm}$ of the flat bottom. The rotor blade probes were calibrated in flows of known speed and the digital output, in $\mathrm{Hz}$, used to calculate the current speed at a given depth in $\mathrm{cm} \mathrm{s}^{-1}$.

Seawater velocities for all 4 experiments were measured daily by Method 1. Typical flow profiles measured by Method 2 are shown in Fig. 2. Results from a number of observations at flows of 5 to $14 \mathrm{~cm} \mathrm{~s}^{-1}$ suggest that the flume boundary layer is $\sim 4 \mathrm{~cm}$ deep without scallops on the flume bottom. With a scallop density of $27 \mathrm{~m}^{-2}$ in the flume, the boundary layer is marginally increased to $6 \mathrm{~cm}$. This compares with up to $20 \mathrm{~cm}$ depth when a $5 \mathrm{~m}$ long bed of blue mussels is present (Wildish \& Kristmanson 1984), when the flume boundary layer is much better developed due to the roughness introduced by the mussel shells. The integrated velocity in the surface $7 \mathrm{~cm}$ of seawater was always 25 to $50 \%$ greater by Method 2 than Method 1. The distribution of the flow when seen from the surface looking to the flume floor shows the effect of drag exerted by the walls, as well as a bias to one side of the channel (Fig. 3), perhaps caused by warping of the plywood walls.

Seston concentration. Daily measures of seston were made including chlorophyll a and adenosene triphosphate (ATP). Particulate chlorophyll a was determined from a $600 \mathrm{ml}$ sample as in Strickland \& Parsons (1968) and ATP from a $15 \mathrm{ml}$ sample filtered on a $0.45 \mathrm{um}$ Swinnex filter. After boiling in Tris buffer, the extracted ATP was determined as in Wildish \& Kristmanson (1984) in a Biolumat photometer. Daily flume water temperatures were also recorded.

Experimental protocol. Growth experiments with scallops were conducted in both the multiple-channel flume and the Kirby-Smith tube apparatus simultaneously. The latter was a replica of that used by KirbySmith (1972) except that the 8 tubes were of black plastic and of a larger diameter, with the flow for each experiment determined daily by dividing the flow volume for a timed period, in $\mathrm{cm}^{3} \mathrm{~s}^{-1}$, by the cross-sectional area of the pipe in $\mathrm{cm}^{-2}$.

Temperature, chlorophyll $a$ and ATP concentrations in the flume (Table 1, Expt 1) were similar to those in inlet seawater to the tube apparatus, given as a mean \pm standard error: temperature $11.60 \pm 0.10^{\circ} \mathrm{C}$, chlorophyll a $2.74 \pm 0.26 \mu \mathrm{gl}^{-1}$, ATP $6.40 \pm 1.06$ $\mathrm{ng} \mathrm{l}^{-1}$. To minimize fouling growth in the tubes, black plastic cylinders were used with 4 scallops in each. The $1.5 \mathrm{~m}$ long by $0.1 \mathrm{~m}$ diameter tubes thus provided a density of 27 scallops $\mathrm{m}^{-2}$, the same density as used in the multiple-channel flume.

In the flume experiments reported here, 16 or 24 adult scallops were placed in each channel at the beginning of the experiment. Since the plan area of 


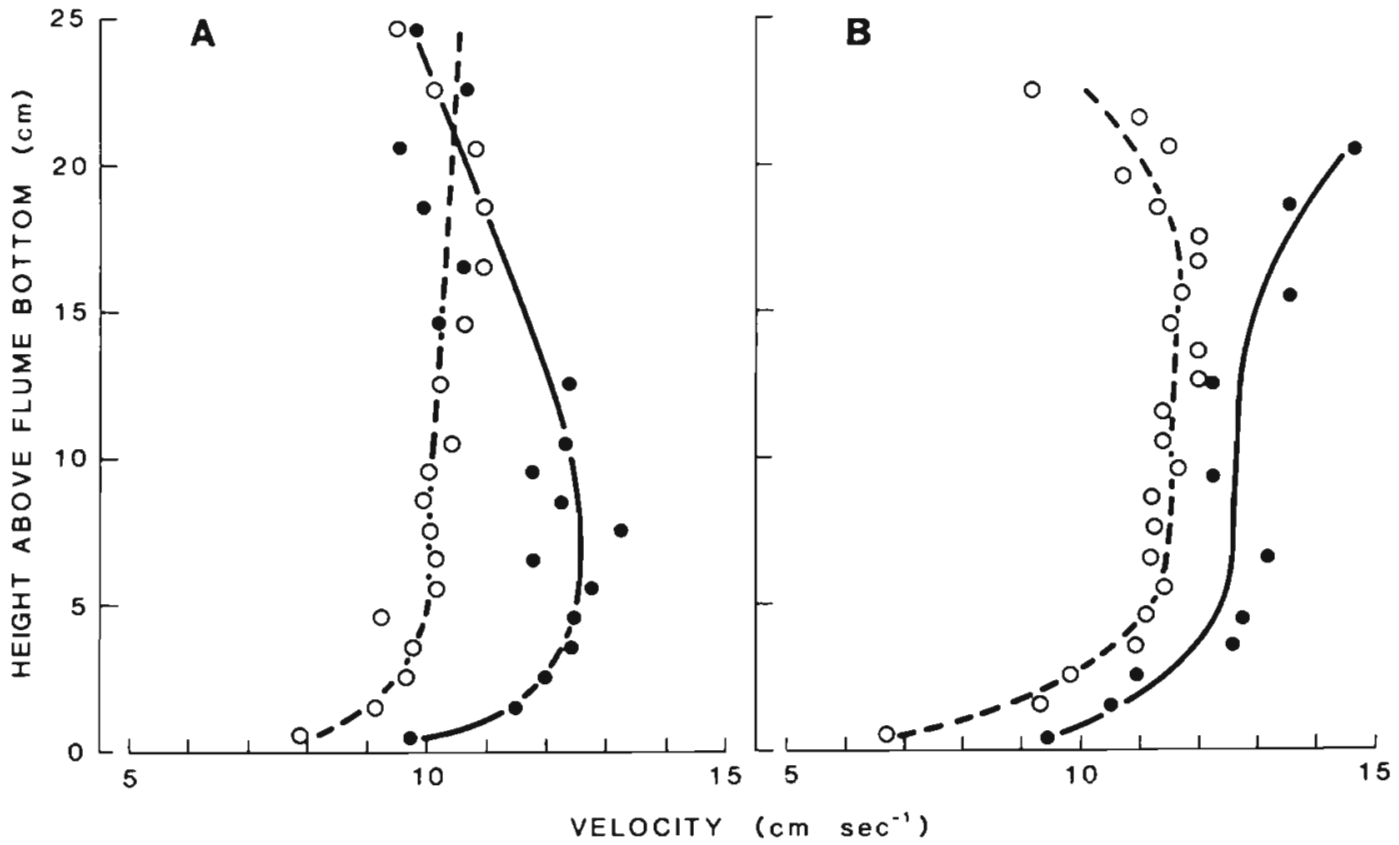

Fig. 2. Velocity profiles determined by Method 2 measured in mid-channel of Channel 2 at the upstream end of each window. (-) At middle window, $1.8 \mathrm{~m}$ from inlet; $(O)$ at downstream window $4.16 \mathrm{~m}$ from inlet. (A) Without scallops; free-stream velocity estimated by Method 1 to be $7.9 \mathrm{~cm} \mathrm{~s}^{-1}$ (B) With scallops at density of $27 \mathrm{~m}^{-2}$; free-stream velocity estimated by Method 1 as 7.9 $\mathrm{cm} \mathrm{s}^{-1}$

Fig. 3. Horizontal distribution of velocity at $2.1 \mathrm{~m}$ downstream from the beginning of Channel 2 at 3 heights, in $\mathrm{cm}$, above the flume bottom. Scallops present at a density of $27 \mathrm{~m}^{-2}$ Free-stream velocity estimated by Method 1 as $8.3 \mathrm{~cm} \mathrm{~s}^{-1}$

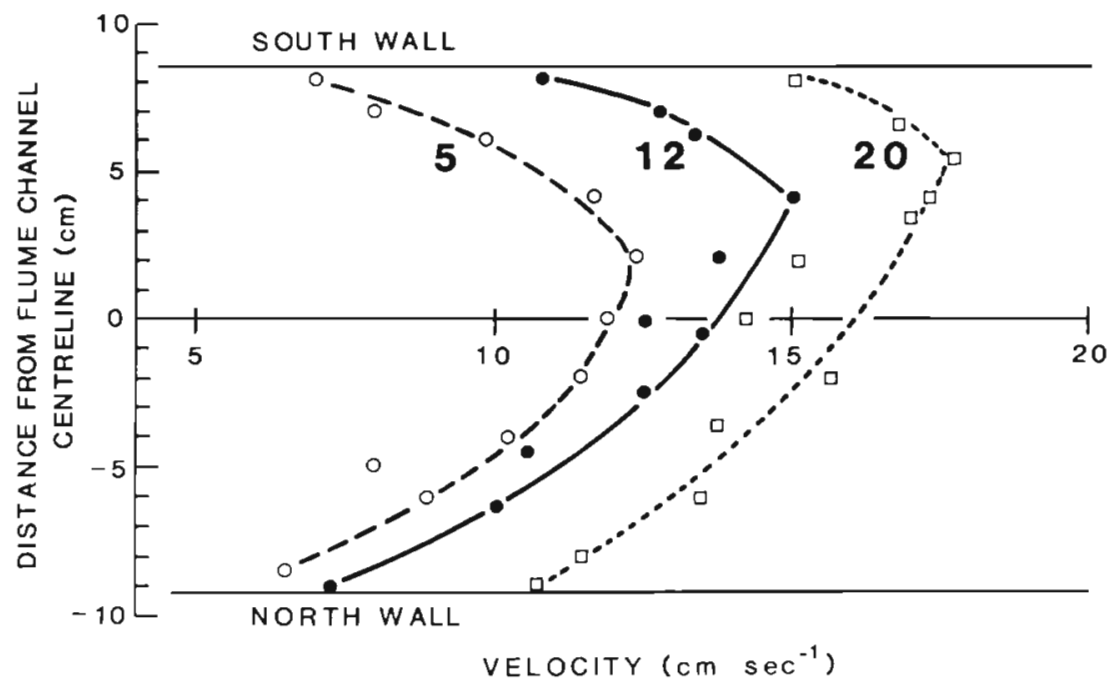

Table 1 Seawater temperature, seston concentration and initial scallop size (mean \pm standard error) during experiments with adult scallop Placopecten magellanicus in the multiple channel flume

\begin{tabular}{|c|c|c|c|c|c|c|c|}
\hline \multirow[t]{2}{*}{ Expt } & \multirow[t]{2}{*}{ Start } & \multirow{2}{*}{$\begin{array}{l}\text { Duration } \\
\text { (d) }\end{array}$} & \multirow{2}{*}{$\begin{array}{c}\text { Temperature } \\
\left({ }^{\circ} \mathrm{C}\right)\end{array}$} & \multicolumn{2}{|c|}{ Seston concentration } & \multicolumn{2}{|c|}{ Initial scallop size } \\
\hline & & & & $\begin{array}{c}\text { Chlorophyll a } \\
\left(\mu \mathrm{g} \mathrm{l}^{-1}\right)\end{array}$ & $\begin{array}{c}\text { ATP } \\
\left(n g l^{-1}\right)\end{array}$ & $\begin{array}{l}\text { Length } \\
\text { (cm) }\end{array}$ & $\begin{array}{c}\text { Wet weight } \\
(g)\end{array}$ \\
\hline $1^{*}$ & 25 Sep 1984 & 20 & $11.7 \pm 0.09$ & $1.63 \pm 0.24$ & $6.10 \pm 0.77$ & $7.04 \pm 0.01$ & $52.47 \pm 0.16$ \\
\hline 2 & 12 Jun 1985 & 29 & $9.8 \pm 0.21$ & $2.90 \pm 0.75$ & $5.10 \pm 0.52$ & $7.95 \pm 0.06$ & $67.97 \pm 1.93$ \\
\hline
\end{tabular}

- With $3 \mathrm{~cm}$ depth of medium/fine sand on flume bottom of Channels 2 and 3 and dead blue mussel shells in Channels 1 and 4 
each channel is $0.88 \mathrm{~m}^{2}$, this represents a scallop density of 18 to $27 \mathrm{~m}^{-2}$. In the periodic flow experiment (Table 1, Expt 2), velocities were manipulated in the multiple-channel flume so that Channel 4 was an optimum flow, and Channel 1 a limiting flow $>10$ $\mathrm{cm} \mathrm{s}^{-1}$ (Wildish et al. 1988). In Channel 2 two-thirds, and in Channel 1 one-third of the time, the flow was at an optimum level for filtration by the giant scallop.

Mean growth differences in shell length or wet weight were compared by Duncan's multiple range test.

\section{RESULTS}

It was necessary to know in the experiments described here that seston depletion did not limit growth at the outlet end of each channel (Wildish \& Kristmanson 1985). Although growth measures comparing the inlet and outlet half of each channel suggested that there were no significant differences, this result was inconclusive because the scallops could move during the experiment. In an experiment reported elsewhere (Wildish et al. 1988), the scallops were glued in place throughout its duration of $33 \mathrm{~d}$. No significant difference between inlet and outlet growth was found at an optimum flow of $\sim 5 \mathrm{~cm} \mathrm{~s}^{-1}$ and it was concluded that at the density used of 27 scallops $\mathrm{m}^{-2}$ or less, seston depletion-limited growth was unlikely with the same size and age of scallops as used in the experiments reported here

\section{Comparison of flume and tube scallop growth and effect of turbulent flow}

Shell length and wet weight was significantly less by Duncan's multiple range test $(p<0.05)$ in the KirbySmith growth tube than all other treatments (Table 2). The average flow in the tube experiment of $3.2 \mathrm{~cm} \mathrm{~s}^{-1}$ is greater than the transition velocity from laminar to turbulent flow of $\sim 2 \mathrm{~cm} \mathrm{~s}^{-1}$ in this apparatus. Because of mixing of scallop-filtered and unfiltered seawater and poor mixing in the radial plane or the tube, some of the seston bypasses the scallops. A possible alternative explanation - that a seston depletion effect was operating - can be discarded based on a fractional flow analysis applicable to pipe flow (Wildish \& Kristmanson 1985). In this analysis, the ratio, F, of the seawater filtered by scallops is calculated in relation to the total flow:

$$
F=\frac{N Y}{283 U}
$$

where $\mathrm{N}=$ inlet to outlet order of successive scallops (from 1 to 4); $Y=$ filtration rate of a scallop $=10 \mathrm{l} \mathrm{h}^{-1}$ treated as a constant; 283 converts the denominator to the flow units of the numerator; and $U=$ current velocity in $\mathrm{cm} \mathrm{s}^{-1}$. Even for the most downstream scallop $\mathrm{F}$ $<1.0$ and consequently, seston depletion-limited growth was unlikely. Because only 4 scallops were used in each tube, it was not possible to compare inlet and outlet growth statistically to confirm this.

In Treatments 1 and 4 (Table 2) where the flume floor was covered with blue mussel shells and the turbulent flow of the boundary layer increased to $\sim 20 \mathrm{~cm}$ above the bottom, scallop growth was not significantly different $(p<0.05)$ from the other 2 treatments, where the boundary layer height was $<6 \mathrm{~cm}$, and the substrate was sand. A hydrodynamically rough surface therefore has no direct effect on growth of the scallop, at least for the limited path lengths available in our flume where the low density of scallops present ensures that seston depletion effects were absent. In the seston conditions of Expt 1 (Table 1) a flow of $\sim 10 \mathrm{~cm} \mathrm{~s}^{-1}$ was not limiting either to shell or wet weight growth.

\section{Effect of periodic flows}

Comparing the growth rates of the control treatments (Channels 1 and 4 ) in Table 3 by Duncan's multiple range test shows that shell length was significantly

Table 2. Placopecten magellanicus. Average daily population growth rates at a density of 27 scallops $\mathrm{m}^{-2}$ in the multiple channel flume and in the Kirby-Smith tube apparatus of Expt 1

\begin{tabular}{|c|c|c|c|}
\hline $\begin{array}{c}\text { Velocity }\left(\mathrm{cm} \mathrm{s}^{-1}\right) \\
\mathrm{X} \pm \mathrm{SE}\end{array}$ & Treatment & $\begin{array}{c}\frac{\mathrm{L}_{1}-\mathrm{L}_{0}}{\mathrm{~L}_{0} \times \mathrm{N}} \times 100 \\
\overline{\mathrm{X}} \pm \mathrm{SE}\end{array}$ & $\begin{array}{c}\frac{W_{1}-W_{0}}{W_{0} \times N} \times 100 \\
\bar{X} \pm S E\end{array}$ \\
\hline $2.9 \pm 0.39$ & 1. Flume with mussel shells & $0.14 \pm 0.01$ & $0.42 \pm 0.02$ \\
\hline $2.9 \pm 0.39$ & 2. Flume with sand & $0.15 \pm 0.01$ & $0.43 \pm 0.02$ \\
\hline $10.0 \pm 0.25$ & 3. Flume with sand & $0.16 \pm 0.01$ & $0.45 \pm 0.02$ \\
\hline $10.0 \pm 0.25$ & 4. Flume with mussel shells & $0.20 \pm 0.02$ & $0.45 \pm 0.03$ \\
\hline $3.2 \pm 0.45$ & 5. Kirby-Smith tube & $0.05 \pm 0.01$ & $0.35 \pm 0.02$ \\
\hline
\end{tabular}


Table 3. Average seawater flow rates in $\mathrm{cm} \mathrm{s}^{-1}$ changed at 0800 and $1600 \mathrm{~h}$, and average population growth rates of $P l a c o p e c t e n$ magellanicus at a density of 27 scallops $\mathrm{m}^{-2}$, during the flow periodicity experiment, Expt 2

\begin{tabular}{|c|c|c|c|c|c|}
\hline & & \multicolumn{4}{|c|}{ Treatment/Channel number } \\
\hline & & $\begin{array}{c}1 \\
\bar{Y}+C E\end{array}$ & $\bar{y}^{2}$ & $\begin{array}{c}3 \\
\bar{Y}\end{array}$ & $\bar{Y}{ }^{4}$ \\
\hline & & $X \pm S E$ & $X \pm S E$ & $X \pm S E$ & $X \pm S E$ \\
\hline \multirow{2}{*}{ Flows } & Day, $8 \mathrm{~h}$ & $13.1 \pm 0.16$ & $13.1 \pm 0.19$ & $4.1 \pm 0.08$ & $4.4 \pm 0.11$ \\
\hline & Night, $16 \mathrm{~h}$ & $12.0 \pm 0.24$ & $5.0 \pm 0.23$ & $11.5 \pm 0.20$ & $4.9 \pm 0.28$ \\
\hline \multirow{2}{*}{ Growth } & Percent daily length growth & $0.053 \pm 0.01$ & $0.104 \pm 0.01$ & $0.056 \pm 0.01$ & $0.095 \pm 0.01$ \\
\hline & Percent daily wet weight growth & $0.37 \pm 0.02$ & $0.41 \pm 0.02$ & $0.36 \pm 0.03$ & $0.41 \pm 0.02$ \\
\hline
\end{tabular}

greater $(p<0.05)$ in the slow flow Channel 4 than in the faster Channel 1. This is consistent with previously reported growth inhibition in the flume at flow velocities $>10 \mathrm{~cm} \mathrm{~s}^{-1}$ (Wildish et al. 1988). Wet weight growth, by contrast, was not different ( $p<0.05$ ) between Channels 1 and 4 and, in fact, biomass growth in all the channels is statistically indistinguishable. Channel 2 shell length growth is statistically identical to the slow flow control Channel 4, suggesting that scallops require exposure to optimum flow conditions for up to two-thirds of the time in order to maximize shell growth. Channel 3 shell length growth is indistinguishable by multiple range test $(p<0.05)$ from the limiting flow control Channel 1 , showing that $\leq$ onethird of the time at optimum flows is insufficient to maximize shell growth.

\section{DISCUSSION}

All methods used for flow measurement have drawbacks in relating flow to bivalve growth responses. Flow within the flume boundary layer decreases logarithmically to zero at the solid flume floor. Velocity measurement within the boundary layer by a rotor of $11.6 \mathrm{~mm}$ diameter will integrate flow to a similar depth and thus misrepresent small flow variations within this depth. Using a point-source flow measurement, e.g. a suitable thermistor anemometer (Muschenheim et al. 1986), it should be possible to improve the accuracy of the flume boundary layer profile. The question then arises at what exact level in the boundary layer are the scallops' behavioral and trophic stimuli received. Because we do not know this and because most field measures will involve flows above the boundary layer. we have concentrated on free-stream flows. Method 1 appears to underestimate this by up to $50 \%$ in our data. Using the data of Fig. 2A fitted to the semi-log law of the wall yields a friction velocity of $0.437 \mathrm{~cm} \mathrm{~s}^{1}$. Taking the bulk flow as that at $5 \mathrm{~cm}$ above the flume bottom, viz. $12.7 \mathrm{~cm} \mathrm{~s}^{-1}$, the law of the wall estimate for velocity at $5 \mathrm{~mm}$ is $8.2 \mathrm{~cm} \mathrm{~s}^{-1}$, at $10 \mathrm{~mm}$ is $11.0 \mathrm{~cm} \mathrm{~s}^{-1}$ and at $15 \mathrm{~mm}$ is $11.4 \mathrm{~cm} \mathrm{~s}^{-1}$. Thus, if a scallop can adjust to these levels, it should experience $65 \%$ at $5 \mathrm{~mm}, 87 \%$ at $10 \mathrm{~mm}$ and $90 \%$ at $15 \mathrm{~mm}$, of the freestream velocity.

We believe that the multiple-channel flume is suitable for simulating natural conditions occurring in the sea. As with all laboratory simulations of nature, however, the experimental situations are simplified. Particular shortcomings of the multiple-channel flume are that its narrow, oblong shape dictates that only 2 directions, up and downstream, for swimming are possible; that where sediment is not provided in the flume there is no opportunity for recessing behavior by the scallop and that bottom roughness is minimized; and that flow in the flume is unidirectional, whereas natural tidal flows periodically reverse. Experimental scallops not provided with sediment in the flume experience a developing boundary layer of 4 to $6 \mathrm{~cm}$, whereas in the sea a welldeveloped logarithmic benthic boundary layer of up to $2 \mathrm{~m}$ in height may be present (Wimbush \& Munk 1970).

The demonstration that shell length and wet weight growth of adult giant scallops in the Bay of Fundy are unrelated with a broad peak of wet weight growth occurring in spring and summer before spawning and a sharp peak in shell length growth immediately after spawning in October (Wildish et al. 1987) is generally supported by the data presented here. One apparently anomalous result found in Expt 1 is the high wet weight growth in September-October, which parallels high shell length growth then. A possible explanation is that the scallops studied by Wildish et al. (1987) had already spawned, whilst those in Expt 1 had not; unfortunately we did not check the spawning condition of the experimental scallops.

We have shown that with nearly identical flows and quality of seston that growth is less in Kirby-Smith growth tubes than in a flume channel at the same density of scallops. This difference is thought to result from the complex flow within pipes as compared to the forming boundary layer within the flume. Due to the more limited mixing within the pipe, some seston bypasses the scallops and consequently is unavailable 
for assimilation and growth. Such flow restrictions are absent in the flume boundary layer. If correct, the same interpretation should apply to growth results obtained with blue mussels in a Kirby-Smith tube (Wildish \& Kristmanson 1985). For tube data on bivalves, we would expect the absolute relationship between flow velocity and growth to be underestimated due to flow restriction although, proportionately, the results would be the same if repeated in a flume.

The experimental finding that growth could be optimized to the prevailing seston quality and concentration, provided that from greater than one-third to two-thirds, or more, of the time could be spent suspension-feeding at non-limiting flow velocities, is consistent with the idea of periodicity in feeding linked to local tidal periodicity. Direct evidence for correlated tidal/digestive periodicity has been found in a number of bivalves (Mathers 1976, Langton 1977, Robinson \& Langton 1980, Palmer 1980). Further work is obviously needed to determine how flow periodicity affects different ages and sizes of scallop, as well as seasonal growth responses to flow periodicity. The present results suggest that in order to monitor the ration of the adult giant scallop the time spent filtering in relation to tidal periodicity must be known in addition to flow velocity and seston quality and concentration.

Acknowledgements. We thank A. DeCoste and R. Hoar for technical assistance with the experiments.

\section{LITERATURE CITED}

Bourne, N. F. (1964). The scallop. Bull. Fish. Res. Bd Can. 145: $1-60$
Caddy, J. F. (1968). Underwater observations on scallop (Placopecten magellanicus) behaviour and drag efficacy. J. Fish. Res. Bd Can. 25: 2123-2141

Kirby-Smith, W. W. (1972). Growth of the bay scallop: the influence of experimental water currents. J. exp. mar. Biol. Ecol. 8: 7-18

Langton, R. W (1977). Digestive rhythms in the mussel, Mytilus edulis. Mar. Biol. 41: 53-58

Mathers, N. F. (1976). The effects of tidal currents on the rhythms of feeding and digestion in Pecten maximus L. J. exp. mar. Biol. Ecol. 24: 271-284

Muschenheim, D. K., Grant, J., Mills, E. L. (1986). Flumes for benthic ecologists: theory, construction and practice. Mar. Ecol. Prog. Ser. 28: 185-196

Palmer, R. E. (1980). Behavioural and rhythmic aspects of filtration in the Bay scallop, Argopecten irradians concentricus (Say), and the oyster Crassostrea virginica (Gmelin). J. exp. mar. Biol. Ecol. 45: 273-295

Robinson, W. E., Langton, R. W. (1980). Digestion in a subtidal population of Mercenaria mercenaria (Bivalvia). Mar. Biol. 58: $173-179$

Strickland, J. D. H., Parsons, T R. (1968). A practical handbook of seawater analysis. Bull. Fish. Res. Bd Can. 167: $1-311$

Wildish, D. J., Kristmanson, D. D. (1984). Importance to mussels of the benthic boundary layer. Can. J. Fish aquat. Sci. 41: 1618-1625

Wildish, D. J., Kristmanson, D. D. (1985). Control of suspension feeding bivalve production by current speed. Helgoländer Meeresunters. 39: 237-243

Wildish, D. J., Kristmanson, D. D., Hoar, R., DeCoste, A., McCormick, S., White, A. W. (1987). Giant scallop feeding and growth responses to flow. J. exp. mar. Biol. Ecol. 113: $207-220$

Wildish, D. J., Peer, D. (1983). Tidal current speed and production of benthic macrofauna in the lower Bay of Fundy. Can. J. Fish. aquat. Sci. 40 (Suppl. 1): 309-321

Wimbush, M., Munk, W. (1970). The benthic boundary layer. In: Maxwell, A. E. (ed.) The sea, Vol. 4. Interscience, New York, p. 731-758 